\title{
DEVLOPMENT AND PERFORMANCE EVALUATION OF LOCAL SUNFLOWER THRESHER
}

\author{
M. A. A., Mady
}

\section{ABSTRACT}

The present study was conducted to develop a threshing unit for a sunflower thresher. Experiments were carried out to evaluate the developed thresher at drum speeds of 400, 500 and600 rpm (8.36, 10.79 and $12.54 \mathrm{~m} / \mathrm{sec}$ ) and four levels of moisture content 10.2, 12.5, 15 and $18.7 \%$. The performance was evaluated in terms of output seed damage, undamaged seeds, threshing losses, threshing efficiency and cleaning efficiency. The lowest seed damaged and threshing losses of 2.6 and 3.25 $\%$ were obtained at drum speed of $400 \mathrm{rpm}(8.36 \mathrm{~m} / \mathrm{sec})$ and moisture content of $10.2 \%$. The highest undamaged seeds, threshing efficiency and machine productivity of 97.4, 94.15\% and $306.12 \mathrm{~kg} / \mathrm{h}$ respectively were obtained at drum speed of $600 \mathrm{rpm}$ and moisture content of $10.2 \%$.

\section{INTRODUCTION}

unflower is an important oil crop in the world. It ranks the second after soybeans with respect to oil production in the world. Its seeds are a rich source of oil. In Egypt, Sunflower seed area increased from 3,000hectares in MY 2010/11 to 5,000hectares in MY 2011/12 and expected to be at the same level in MY 2012/13. In MY $2011 / 12$, sunflower oil production increased by 7 TMT from the previous season, and expected to be at the same range of about 28TMT in MY 2012/13. A slight recovery is expected in MY 2012/13. However, the mechanical threshing problem process summarized in causing damage for seeds and existence some un-threshed seeds that is resulted in reduction of the threshing efficiency and seeds quality. This problem obviously appeared during sunflower threshing that is due to the nature of the seeds (Food Outlook, November 2012).

Sudajan (2002) the threshing unit plays a key role in determining the performance of a thresher.

\section{Engineering Department, Faculty of Agriculture, Suez Canal University, 41522 Ismailia, Egypt.}


Therefore, this study was conducted to study the effect of threshing drum speeds and feed rates; to determine the best drum speed and feed rate; and to determine the grain and material other than grain (MOG) separation over the length of the threshing drum. Rizviet et al. (1993) compared the performance of different threshing drums for sunflower threshing. The spike/peg tooth, rasp bar and rubber strip cylinder with their respective concaves were used. The study showed that the peg-type cylinder with a speed range of 400-500 $\mathrm{min}^{-1}$ and a concave clearance range from 25 to $30 \mathrm{~mm}$ can be used for a sunflower threshing unit. Naravani and Panwar (1994) studied the effects of the impact mode of threshing on the thresh ability of a sunflower crop. The results showed that threshing efficiency increased as the impact energy increased at seed moisture contents ranging from 5_76 to $13.56 \%$ wet basis (wb). A threshing efficiency of $71 \%$ with $9.7 \%$ (wb) seed moisture content at an energy level of $20.6 \mathrm{~N} \mathrm{~m}$ was observed. Bansal et al. (1994) evaluated different sunflower threshers. Sunflower threshers based on axial flow designs were mostly used. It was concluded that sunflower should be threshed at a cylinder speed of $6.5 \mathrm{~m} / \mathrm{s}$ with a feed rate of $1500-2000 \mathrm{~kg} / \frac{1}{2} \mathrm{head} / \mathrm{h}$ at a grain moisture content of $30 \%$ (wb). Bhutta et al.(1997) compared the performance of a locally made sunflower thresher and a combine harvester. The thresher was operated with a tractor power-take-off (PTO). The power-operated sunflower thresher had an output capacity of 447 $\mathrm{kg} 1 / 2 \mathrm{seed} / \mathrm{h}$ with a threshing efficiency of $97.3 \%$ and a breakage of $4.87 \%$. The combine harvester threshing drum consisted of eight rasp bars $1.04 \mathrm{~m}$ in length and was $600 \mathrm{~mm}$ in diameter. The combine harvester had an output capacity of $1000 \mathrm{~kg} 1 / 2 \mathrm{seed} / \mathrm{h}$ with a threshing efficiency of $98.7 \%$ and breakage of $0.26 \%$. Peeneej dangang (1997) evaluate some of threshing machine for threshing sunflower. The results obtained indicated that these threshers are not appropriate for threshing sunflower, as grain damage may be as much as $4-10 \%$, cleaning efficiency only $87-92 \%$, and grain losses 3-13\%. Some threshers recorded grain losses of 20-35\%.

Anil et al. (1998) designed and developed a prototype threshing machine for sunflower seeds, using basic principles adopted for cereal threshers. Test results indicated that, the optimal thresher performance was achieved at $9-13 \%$ moisture content, $180 \mathrm{~kg} / \mathrm{h}$ feed rate and $500 \mathrm{rpm}$ cylinder 
speed. Khater (2000) indicated that threshing efficiency, cleaning efficiency and seed damage increased by deceasing moisture content. Also he indicated that the best moisture content that gave the lowest seed damage and seed losses, and highest of threshing and cleaning efficiency is $14 \%$. Sudajan et al. (2002) stated that, the type of threshing drum, drum speed and feed rate affected the output capacity, threshing efficiency, grain damage and grain losses during sunflower threshing. The output capacity, threshing efficiency, grain damage, grain losses and specific energy consumption at $750 \mathrm{~min}^{-1}$ drum speed and $3000 \mathrm{~kg} 1 / 2$ head/ h feed rate were $1038 \mathrm{~kg} / \mathrm{h}, 99.99 \%, 1.39 \%, 0.36 \%$ and $3.01 \mathrm{kWh}$ $/ t$, respectively. Billy (2004) reported that the sunflower harvesting at a high moisture content (18 to 20\%) normally results in higher yields, less bird damage, and less shattering or dropping of heads than when seeds are harvested at a lower moisture content. Hamada El-Khateeb et al. (2008) concluded that, The optimum operating condition for El-Shams threshing machine are at drum speed of $14.65 \mathrm{~m} / \mathrm{s}$, feed rate $10 \mathrm{~kg} / \mathrm{min}$. and sunflower heads moisture content of $17.07 \%$. Goel et al. (2009) developed Two types of low-cost sunflower threshers (wire mesh type and perforated GI sheet type) and their performance was compared with pedal operated thresher and the traditional method. The test was conducted at four levels of moisture content (db) i.e., 13.84, 11.23, 10.50 and $8.38 \%$ for MSFH-17 variety of sunflower crop with different cub diameter ranging from $16-19 \mathrm{~cm}$. The threshing capacity of the threshers increased with decrease in moisture content from 13.84 to 10.50 percent below which it decreased for all the treatments. The mechanical damage decreased with decrease in seed moisture content and threshing efficiency increased with decrease in moisture content in all the treatments. Based on highest threshing capacity, lowest cost of threshing and a grain breakage of less than 2 per cent, the optimum seed moisture content was found to be 10.50 percent for threshing of sunflower crop. As highest threshing capacity and lowest cost of threshing were observed with wire mesh type thresher, this may be recommended for adoption by small and marginal farmers of the state.

Nowadays, Farmers in most areas of Egypt thresh sunflower manually. No thresher to thresh local sunflower is available in Egypt because other 
crops are being harvested and threshed at the same time. In order to increase sunflower production, the development of a sunflower thresher has therefore become important. So, the objectives of the present study are to developed and evaluate the performance of a local sunflower thresher.

\section{MATERIALS AND METHODS}

The experiments were carried out at the Experimental Farm of Faculty of Agriculture, Suez Canal University. sunflower seed of Sakha 53 Varity was used in this study. The seeds were manual planted on ridges at distance of $20 \mathrm{~cm}$ between plants. The average sunflower heads and seeds physical properties were as shown in Table (1).

Table (1). Sunflower heads and seeds physical properties.

\begin{tabular}{|c|c|c|c|}
\hline $\begin{array}{c}\text { Head diameter, } \\
\mathrm{cm}\end{array}$ & $\begin{array}{c}\text { Mass of } 1000 \\
\text { seeds, } \mathrm{g}\end{array}$ & $\begin{array}{c}\text { Seed length, } \\
\mathrm{mm}\end{array}$ & $\begin{array}{c}\text { Seed Width, } \\
\mathrm{mm}\end{array}$ \\
\hline 20.8 & 84.6 & 12.25 & 5.4 \\
\hline
\end{tabular}

\section{The developed sunflower thresher:}

The machine under study was used for corn shelling, some modifications were conducted on this machine to fit sunflower threshing as follows:

1- Change the thresher concave which mad of galvanized iron sheet of $1 \mathrm{~mm}$ thickness pierced to hole of $13 \mathrm{~mm}$ diameter and fitted under the cylinder.

2- Change the clearance between the concave and cylinder to be $40 \mathrm{~mm}$ while in old machine was $70 \mathrm{~mm}$.

3- Connecting the electric motor by Invertor device (AC 650 series) to provide or reduce the rotary speed of the electric motor.

The developed mechanical thresher for sunflower threshing was constructed at Agric. Mech. Dept., Faculty of Agric., Suez Canal Univ. The thresher consists of an iron cylinder length of $660 \mathrm{~mm}$ and $260 \mathrm{~mm}$ diameter assembled on an axial shaft of $30 \mathrm{~mm}$ diameter rested on two bearing fixed on the frame. The cylinder circumference is divided into three zones. The first zone facing the feeding opening fixed on the circumference rubbery fingers. The second zone fixed on the circumference iron fingers and the third zone facing the expel opening fixed on the circumference hammers to expel the sunflower heads outside on the rear of sunflower thresher. All fingers fixed on 
the cylinder circumference. The thresher concave made from galvanized iron sheet of $1 \mathrm{~mm}$ thickness pierced to hole of $13 \mathrm{~mm}$ diameter and fitted under the cylinder. Two pulleys at the same diameter $(100 \mathrm{~mm})$ fixed on each of motor and cylinder shaft. The electric motor Connected by device to provide or reduce the rotating speed of the motor. The powered by an electric motor (1 Hp) as shown in Figs 1 and 2.

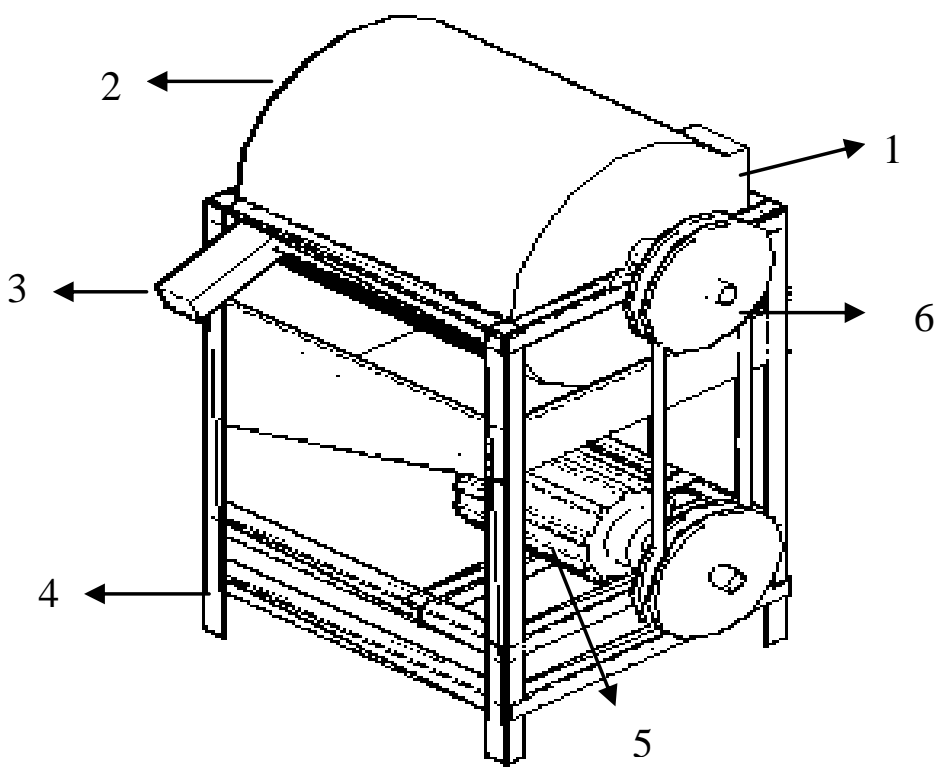

1- Feeding opening

4- Frame of machine
2- Cover

5- Electric motor
3- Expel opening

6- Transmission pulleys

\section{Fig. 1. The sunflower thresher}

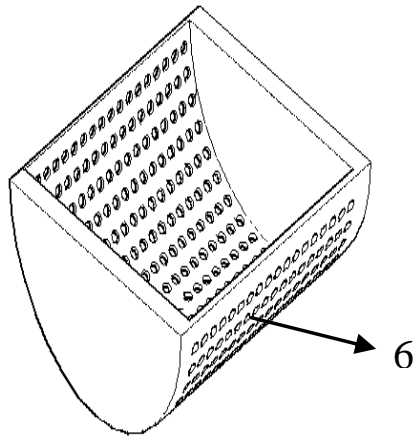

1- Shaft

4- Rubbery fingers
2- Cylinder

5- Hammers

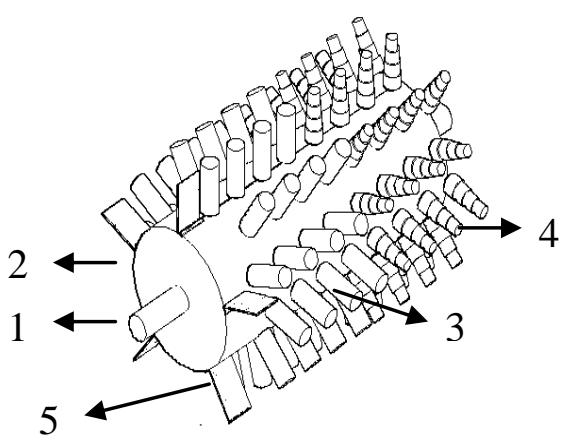

3- Iron fingers

6- Galvanized iron sheet

Fig. 2. The components of concave and drum for a sunflower thresher 
The developed sunflower thresher was tested to study some parameters affecting on the threshing operation as follows:

1-Three drum rotary speed 400, 500 and $600 \mathrm{rpm}(8.36,10.79,12.54$ $\mathrm{m} / \mathrm{sec}$ ).

2-Four levels of moisture content of 10.2, 12.5, 15 and 18.7\%).

The thresher performance was studied through:-

- Damaged seeds percentage

- Undamaged seeds percentage

- Threshing losses percentage
- Seed Productivity

- Cleaning efficiency

- Threshing efficiency.

\section{Damaged and undamaged seeds percentage.}

Three random samples of sunflower seeds were taken after threshing operation. Each sample weighted and was divided into two portions, damaged seeds and undamaged seeds. The percentage of the each portion was calculated as follows:

$$
\begin{aligned}
& \text { Ds }=\left(M_{1} / M\right) * 100 \% \\
& \text { UDs }=\left(M_{2} / M\right) * 100 \%
\end{aligned}
$$

where's:

$$
\begin{aligned}
& \text { Ds = damaged seeds, } \% \\
& \text { UDs = undamaged seeds, } \% . \\
& \mathrm{M}_{1}=\text { mass of damaged seeds, } \mathrm{kg} . \\
& \mathrm{M}_{2}=\text { mass of undamaged seeds, } \mathrm{kg} . \\
& \mathrm{M}=\text { total mass of seeds, } \mathrm{kg} .
\end{aligned}
$$

\section{Threshing losses.}

Three random samples of sunflower were fed into the thresher. The unthreshing seeds were threshing manually and collected with the seeds exit from expel opening and weighted, $\mathrm{kg}$. The threshing losses percentage (Ls)was calculated as follow:

$$
\text { Ls }=(\text { Mloss th } / \text { Mtot }) * 100 \%
$$

where's:

$$
\begin{aligned}
& \text { Mloss th = mass of threshing losses, } \mathrm{kg} \\
& \mathrm{M}_{\mathrm{tot}}=\text { total mass of seeds, } \mathrm{kg}
\end{aligned}
$$

\section{Threshing efficiency:}

Threshing efficiency of sunflower thresher was estimated as follows: 


$$
E_{t h}=\left(M_{s}-M_{t h}\right) / M_{s} * 100 \%
$$

where's:

$$
\begin{aligned}
& \text { Eth }_{\text {= threshing efficiency, } \%} \\
& \mathrm{M}_{\mathrm{th}}=\text { mass of un-threshed seed, } \mathrm{kg} . \\
& \mathrm{M}_{\mathrm{s}}=\text { total seed mass, } \mathrm{kg} .
\end{aligned}
$$

\section{Machine productivity:}

Three samples each of $5 \mathrm{~kg}$ of sunflower were fed into the thresher for each treatment and the threshing time in minutes was recorded. The machine productivity was calculated as follow:

$$
\mathbf{M p}=(\mathbf{M} * 60) / \mathrm{T}
$$

where's:

$$
\begin{aligned}
& \mathrm{Mp}=\text { machine productivity, } \mathrm{kg} / \mathrm{hr} . \\
& \mathrm{M}=\text { mass of seeds sample, } \mathrm{kg} . \\
& \mathrm{T}=\text { threshing time, in minutes. }
\end{aligned}
$$

\section{Cleaning efficiency:}

Three samples each of $5 \mathrm{~kg}$ of sunflower were fed into the thresher for each treatment. After completed threshing operation the seeds of each treatment were saving and divided into two portions. The total seed mass and the mass of impurities. The cleaning efficiency was calculated as follows:

$$
E_{c l}=\left(M_{s}-M_{a}\right) / M_{s} * 100 \%
$$

whereas:

$$
\begin{aligned}
& \mathrm{E}_{\mathrm{cl}}=\text { cleaning efficiency, } \% \\
& \mathrm{M}_{\mathrm{a}}=\text { mass of impurities, } \mathrm{kg} \\
& \mathrm{M}_{\mathrm{s}}=\text { total seed mass, } \mathrm{kg}
\end{aligned}
$$

\section{RESULTS AND DISSECTION}

Effect of moisture content and drum rotary speed on the thresher performance.

The results in Fig. 3 showed that, there is a positive relationship between the seed moisture content and drum rotary speed on the damaged seeds percentage. The mechanical damage was observed to be decreased with decrease in seed moisture content. Decreasing moisture content from 18.7 to $10.2 \%$ tends to decrease the average of damaged seeds percentage from 
6.1 to $3.25 \%$ at drum rotary speed ranged from 600 to $400 \mathrm{rpm}$. This may be due to the reason that at higher moisture content the seeds becomes soft, which is liable to break due to shear force while with decrease in moisture content, the hardness of seed increases causing less breakage. At the same time, The results indicated that, the seed damage increased with an increase in drum speed. Increasing drum rotary speed from 400 to 600 $\mathrm{rpm}$ increased the average of damaged seeds percentage from 3.6 to $5.5 \%$ at seed moisture content ranged from 10.2 to $18.7 \%$. This increase was due to higher impact levels imparted to the crop during threshing at higher drum speeds.

The results in Fig. 4 revealed that, there is an inverse relationship between the seed moisture content and drum rotary speed on the undamaged seeds percentage. Decreasing moisture content from 18.7 to $10.2 \%$ led to increase the average of undamaged seeds percentage from 93.9 to $96.75 \%$ at drum rotary speed ranged from 600 to $400 \mathrm{rpm}$. At the same time, decreasing drum rotary speed from 600 to $400 \mathrm{rpm}$ increased the average of undamaged seeds percentage from 94.5 to $97.4 \%$ at seed moisture ranged from 18.7 to $10.2 \%$. The highest undamaged seeds percentage $97.4 \%$ was obtained at drum rotary speed of $400 \mathrm{rpm}$ and moisture content of $10.2 \%$.

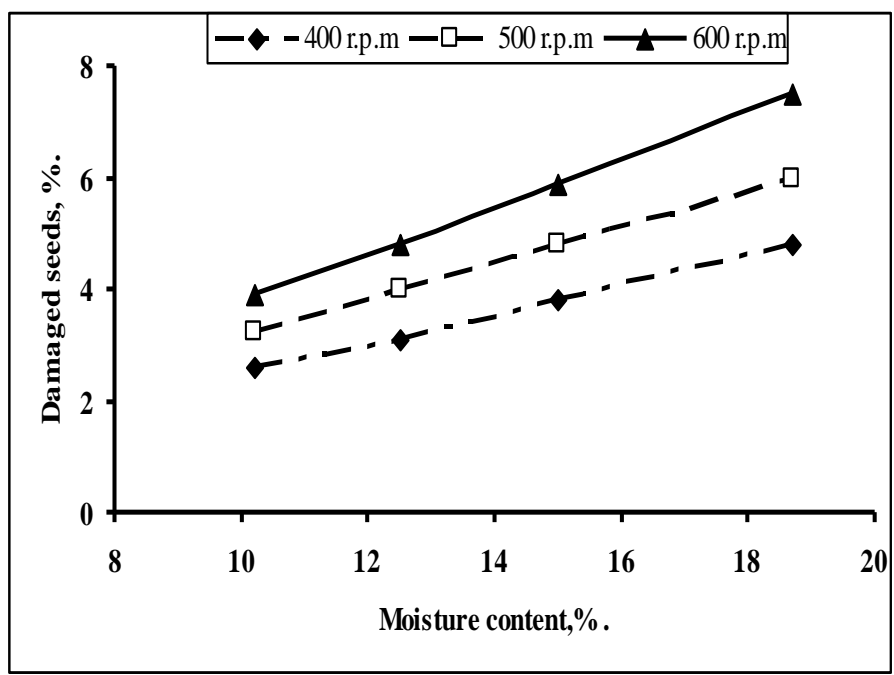

Fig. 3. Effect of moisture content and drum rotary speed on the damaged seeds percentage. 


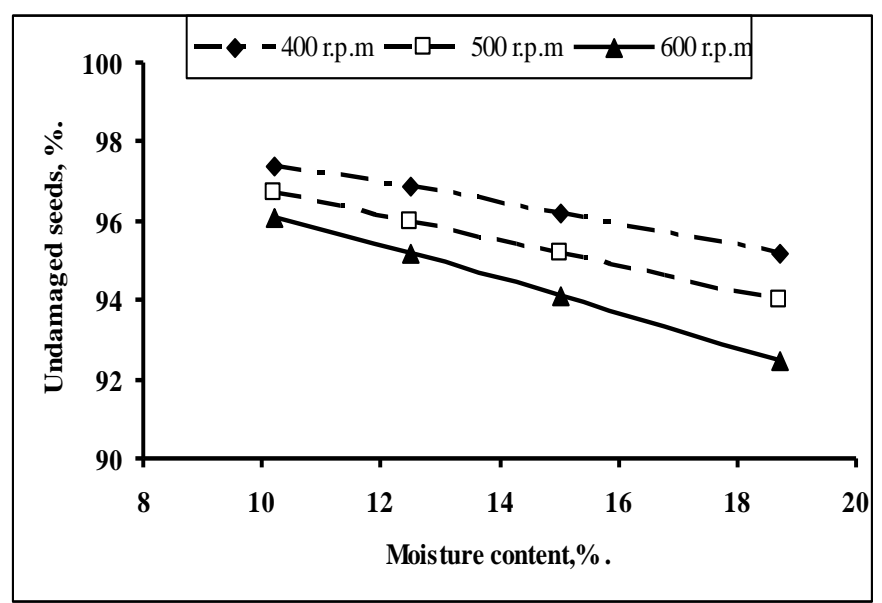

Fig. 4. Effect of moisture content and drum rotary speed on the undamaged seeds percentage.

The results in Fig. 5 revealed that, there is a positive relationship between the seed moisture content and drum rotary speed on the seeds losses percentage. Increasing moisture content from 10.2 to $18.7 \%$ tends to increase the average of seed losses percentage from 4.12 to $7.9 \%$ at drum rotary speed ranged from 400 to $600 \mathrm{rpm}$. The results may be due to the increase of the grain moisture content of sunflower heads, thus the grains were not easily threshed and gave more total seed losses. While increasing drum rotary speed from 400 to $600 \mathrm{rpm}$ increased the average of seeds losses percentage from 4.5 to $7.3 \%$ at seed moisture ranged from 10.2 to $18.7 \%$. The highest seed losses percentage of $10 \%$ was obtained at drum rotary speed of $600 \mathrm{rpm}$ and moisture content of $18.7 \%$. The least seed losses percentage of $3.25 \%$ was obtained at drum rotary speed of $400 \mathrm{rpm}$ and moisture content of $10.2 \%$.

The results in Fig. 6 indicated that, increasing moisture content from 10.2 to $18.7 \%$ tends to decrease the average of threshing efficiency from 92.6 to $86 \%$ at drum rotary speed ranged from 400 to $600 \mathrm{rpm}$. These results due to reduce moisture content of sunflower heads tends to increase separation efficiency of seeds from heads consequently increase threshing efficiency. While increasing drum rotary speed from 400 to $600 \mathrm{rpm}$ led to increase the average of threshing efficiency from 87.2 to $91.9 \%$ at seed moisture ranged from 10.2 to $18.7 \%$. These results may be due to increasing the impact action of the threshing drum on the threshed material (sunflower heads) which is directly proportional with drum 
speed. Increasing the impact action due to increasing drum speed increased the kinetic energy of the threshing material which differ widely from seeds to sunflower heads trashes, consequently the seeds will be quicker and run away from the trashes. Therefore the separating efficiency will be increased and increased the threshing efficiency. The highest threshing efficiency of $94.15 \%$ was obtained at drum rotary speed of $600 \mathrm{rpm}$ and moisture content of $10.2 \%$. The least threshing efficiency of $82.5 \%$ was obtained at drum rotary speed of $400 \mathrm{rpm}$ and moisture content of $18.7 \%$.

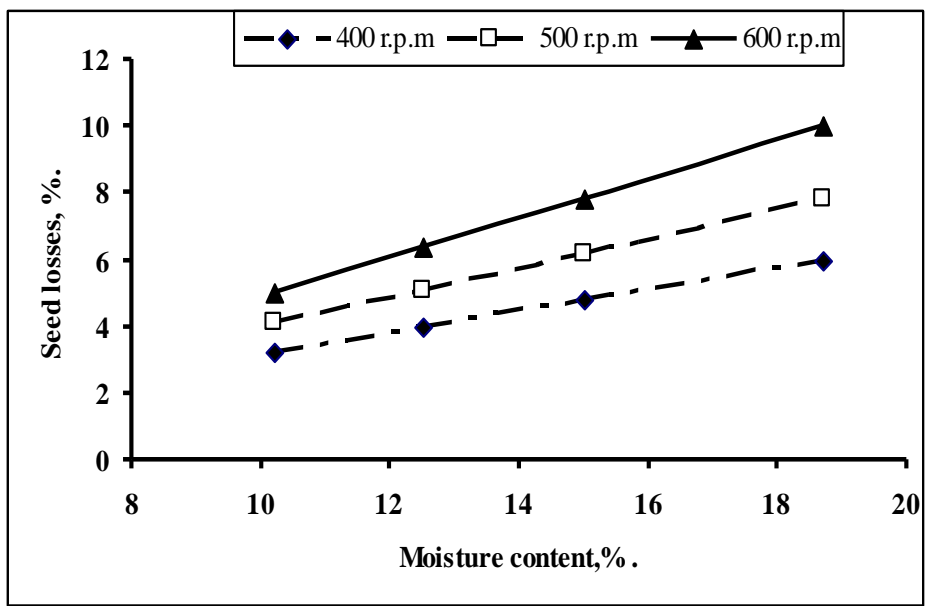

Fig. 5. Effect of moisture content and drum rotary speed on the seed losses percentage.

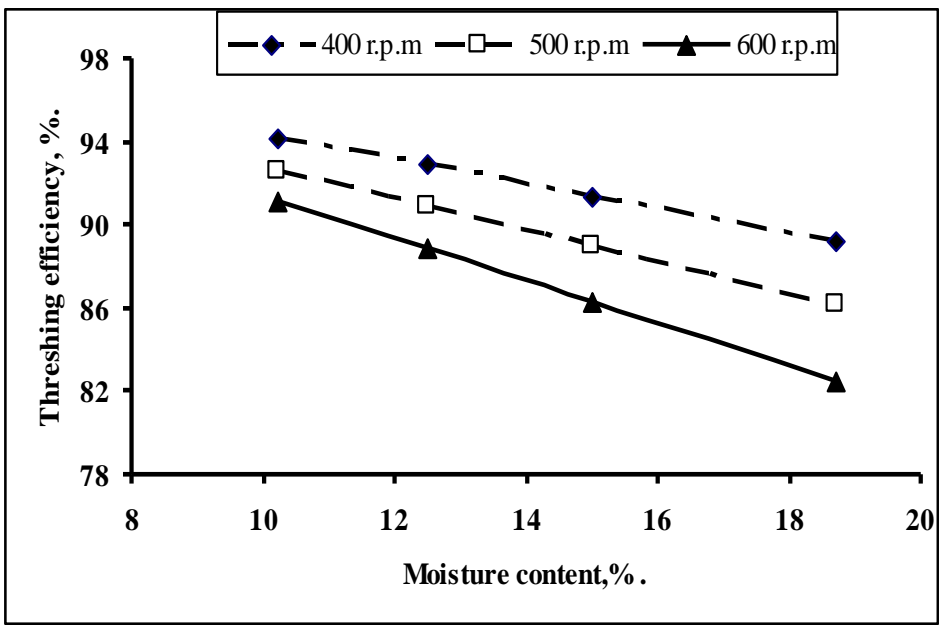

Fig. 6. Effect of moisture content and drum rotary speed on the threshing efficiency. 
The results in Fig. 7 indicated that, increasing drum rotary speed and decreasing seeds moisture content led to increase the machine productivity $(\mathrm{kg} / \mathrm{h})$. Decreasing moisture content from 18.7 to $10.2 \%$ increased the average of machine productivity from 163.22 to 292.25 $\mathrm{kg} / \mathrm{h}$ at drum rotary speed ranged from 400 to $600 \mathrm{rpm}$. On the other hand increasing drum rotary speed from 400 to $600 \mathrm{rpm}$ increased the average of machine productivity 209.6 to $266.6 \mathrm{~kg} / \mathrm{h}$ at seed moisture content ranged from 10.2 to $18.7 \%$. The highest machine productivity 306.12 $\mathrm{kg} / \mathrm{h}$ was obtained at drum rotary speed of $600 \mathrm{rpm}$ and moisture content of $10.2 \%$. The least machine productivity $140 \mathrm{~kg} / \mathrm{h}$ was obtained at drum rotary speed of $400 \mathrm{rpm}$ and moisture content of $18.7 \%$.

The results in Fig. 8 indicated that, decreasing drum rotary speed and increasing seeds moisture content led to increase the cleaning efficiency. Increasing moisture content from 10.2 to $18.7 \%$ increasing the average of cleaning efficiency from 86.7 to $89.8 \%$ at drum rotary speed ranged from 400 to $600 \mathrm{rpm}$. On the other hand, decreasing drum rotary speed from 600 to $400 \mathrm{rpm}$ tends to increase the average of cleaning efficiency from 85.4 to $90 \%$ at seed moisture content ranged from 10.2 to $18.7 \%$. The highest cleaning efficiency $92 \%$ was obtained at drum rotary speed of $400 \mathrm{rpm}$ and moisture content of $18.7 \%$. The least seeds cleaning efficiency $84.4 \%$ was obtained at drum rotary speed of $600 \mathrm{rpm}$ and moisture content of $10.2 \%$.

\section{SUMMARY AND CONCLUSION}

\section{The result in the present study could be summarized in the following} conclusion:

1. There is a positive relationship between the seed moisture content and drum rotary speed on the damaged seeds and seed losses percentage. Increasing moisture content from 10.2 to $18.7 \%$ and drum rotary speed from 400 to $600 \mathrm{rpm}$ led to increase the average of damaged seeds and seed losses percentage from 3.25 to $6.1 \%$ and from 4.12 to $7.9 \%$ respectively. The least seed damaged and seed losses percentages of 2.6 and $3.25 \%$ were obtained at drum rotary speed of $400 \mathrm{rpm}$ and moisture content of $10.2 \%$. 


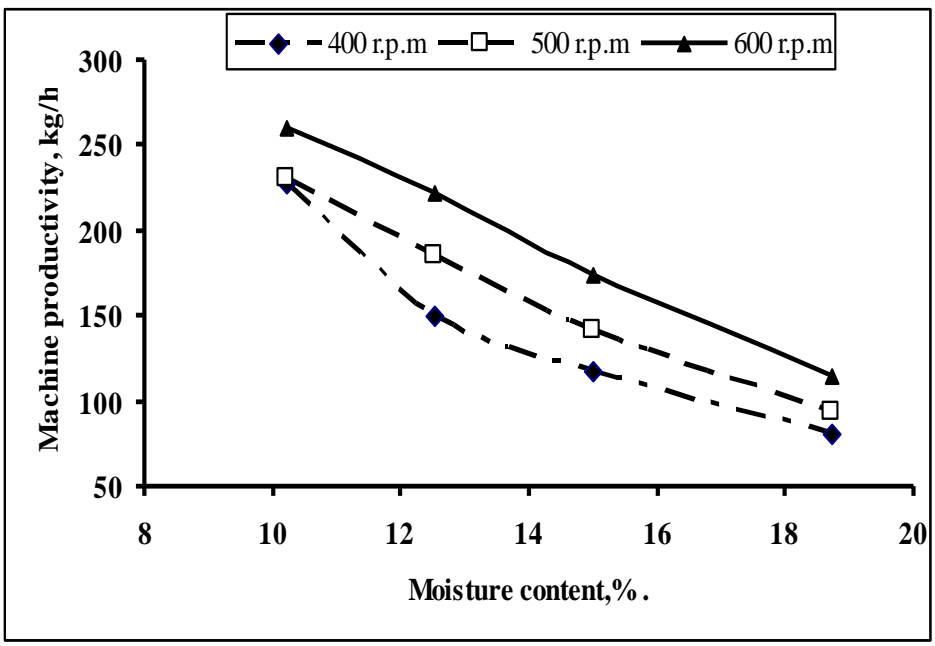

Fig. 7. Effect of moisture content and drum rotary speed on the machine productivity.

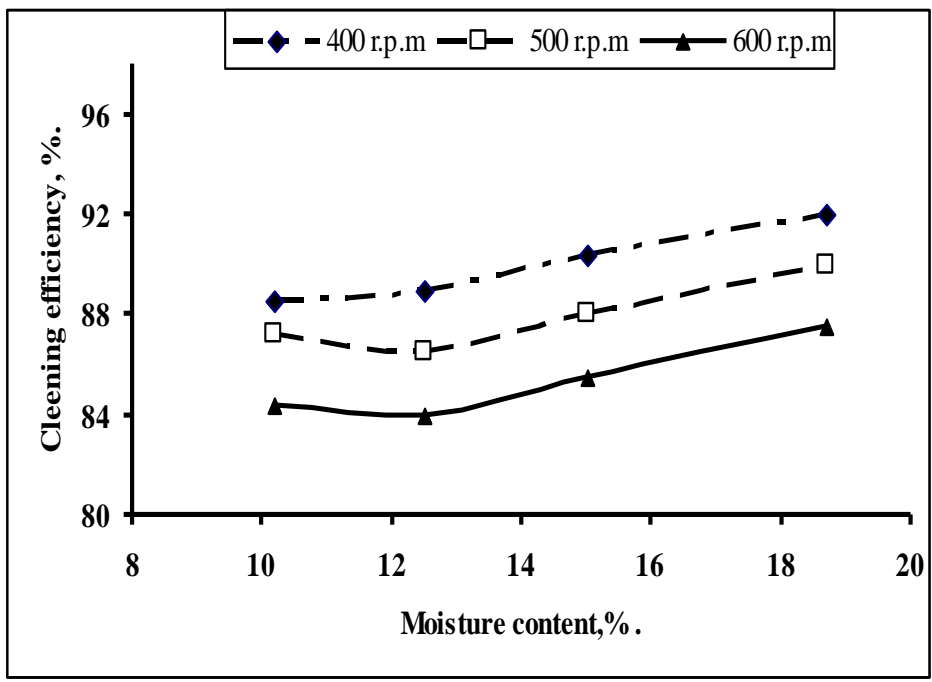

Fig. 8. Effect of moisture content and drum rotary speed on the seed cleaning efficiency.

2. Decreasing moisture content from 18.7 to $10.2 \%$ and drum rotary speed from 600 to $400 \mathrm{rpm}$ tends to increase the average of undamaged seeds percentage from 93.9 to $96.75 \%$. The highest undamaged seeds percentage of $97.4 \%$ was obtained at drum rotary speed of $400 \mathrm{rpm}$ and moisture content of $10.2 \%$.

3. Increasing drum rotary speed and decreasing seeds moisture content led to increase the threshing efficiency and machine productivity. The 
highest threshing efficiency and machine productivity $94.15 \%$ and $306.12 \mathrm{~kg} / \mathrm{h}$ were obtained at drum rotary speed of $600 \mathrm{rpm}$ and moisture content of $10.2 \%$.

4. Decreasing drum rotary speed and increasing seeds moisture content led to increase the cleaning efficiency. The height cleaning efficiency $92 \%$ was obtained at drum rotary speed of $400 \mathrm{rpm}$ and moisture content of $18.7 \%$.

\section{REFERENCES}

Anil J; Guruswamy T; Desai SR; Basavaraj T and Joshi A (1998). Effect of cylinder speed and feed rate on the performance of thresher. Journal of Agricultural Sciences, 4, 1120-1123.

Bansal N K; Agarwal S and Sharma T R (1994). Performance evaluation of a sunflower thresher. A paper presented at the XXIX Annual Convention of India Society of Agricultural Engineering, India, February 10-12, 1994.

Bhutta M S; Sabir M S and Javaid Z (1997). Comparative performance of different methods of sunflower threshing. Agricultural Mechanization in Asia, Africa and Latin America, 28(3), 65-67.

Billy, E. W. (2004). Sunflower production guide for west central texas. PP: (1-15).

FAO-Trade and Markets Division. Oilseeds market summary. Food Outlook, November 2012.

Goel A K; Behera D; Swain S and B K Behera (2009). Performance evaluation of low- cost manual sunflower thresher. Indian J. Agric Res., 43(1): 37-41.

Hamada El-Khateeb, Husain Sorour, M. I. Saad(2008). Operating factors affecting using two different threshing machine for threshing sunflower head. Agric. Mech. And Eng. Between existing and prospected: 251-270.

Khater, A. E. A. (2000). Mechanization of sunflower threshing. M. Sc. Thesis. Agric. Eng. Dept, Fac. Of Agric Mansoura Univ.

Naravani N B; Panwar J S (1994). Effect of impact mode of threshing on thresh ability of sunflower crop. A paper presented at XXIX annual Convention of India Society of Agricultural Engineering, Bhopal, India. 
Peeneej dangang S (1997). Field tests of an axial flow rice thresher for sunflower threshing. A paper presented at Seminar II, Agricultural Engineering Department and Khon Kaen University, Thailand.

Rizviet S, H. A; Amjad N and M. A. Shaheen (1993). Comparative performance of different threshing drums for sunflower. Agricultural Mechanization in Asia, Africa and Latin America, 24(1), 23-27.

Sudajan S, Salokhe V M and Triratanasirichai K (2002). Effect of type of drum, drum speed and feed rate on sunflower threshing. Bios stems Engineering. 83(4), 413-421.

Sudajan S (2002). Development of a sunflower thresher. Asian Inst. Tech. D. Eng. Dissertation No. AE-02-2 (sudajan et al. 2002).

\section{الملخص العربي \\ تطوير وتثيبم أداء آلة محلية لدراس عباد ألثمس \\ * محمد عطية ماضيث}

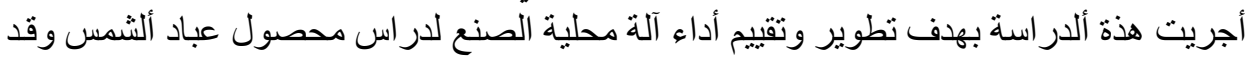

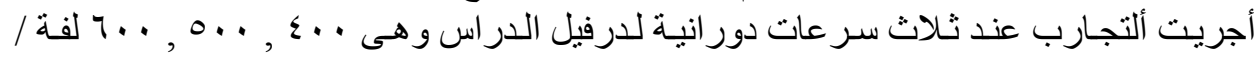

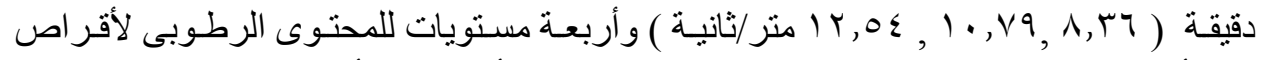

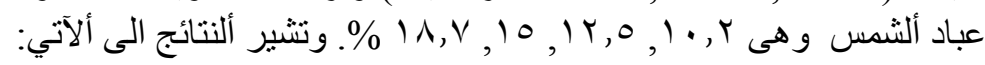

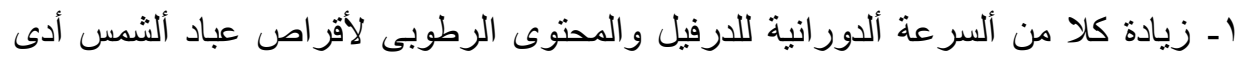

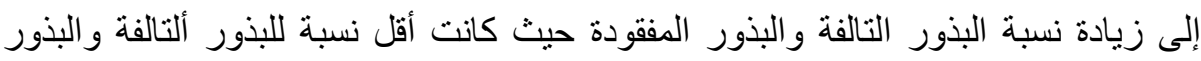

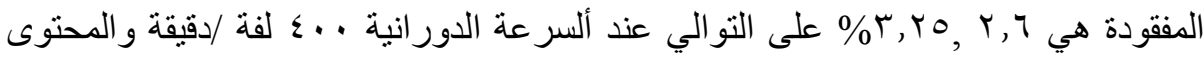

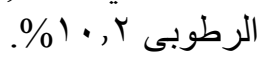

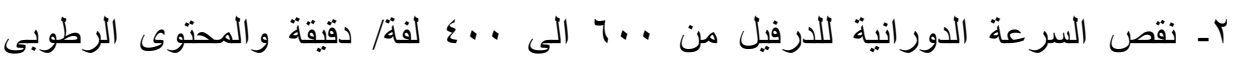

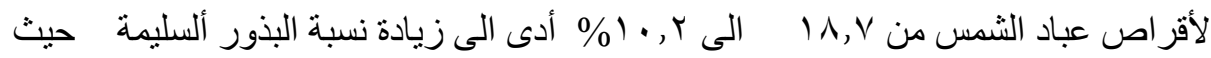

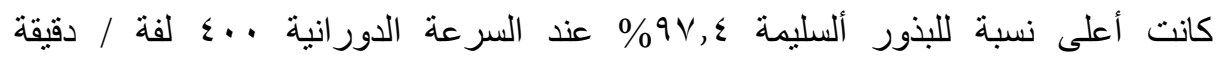

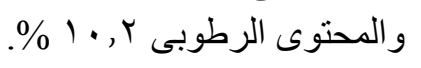

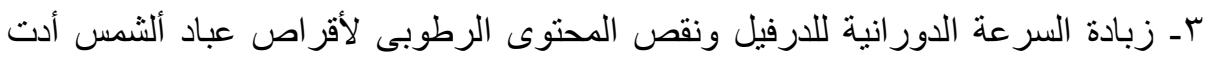

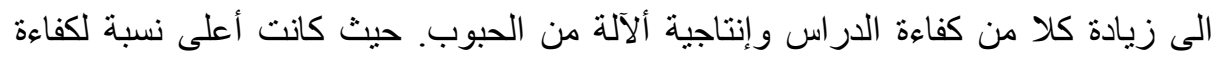

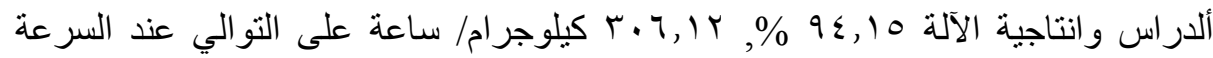

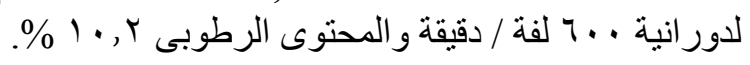

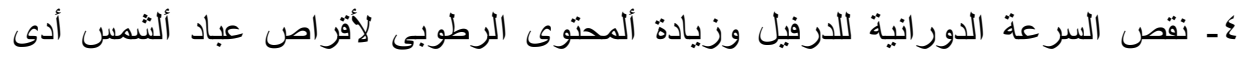

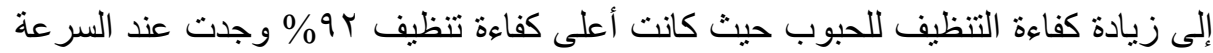

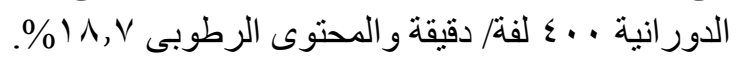

*أستاذ مساعد بقسم ألهندسة الزراعية ـ كلية الزراعة - جامعة قناة السويس. 